\title{
THE BACKGROUND OF LOCAL FOOD-BASED ECONOMY DEVELOPMENT IN THE EGER WINE REGION
}

\author{
Csaba Ruszkai - Mercédesz Németh - Konrád Kiss - Ilona Pajtók
}

\begin{abstract}
This study reveals the background situation of local food-based economy in the Eger Wine Region. Local food economy is mostly in initial phase in the region because of small scale supply, barely known local food producers and their supply, weak connections between producers and representation of interests, or major labour issues. Despite all these there are advantageous economic environment for development local food-based economy in the area, because the critical mass of producers is still active in the region and consumer's demand is significant. Tourism provides standing demand for local goods as well. A comprehensive development of market infrastructure would increase the existence of these unique economic entities.
\end{abstract}

Keywords: local food, rural development, short supply chains, strategic planning 


\section{Introduction}

Creating of local food-based supply chains are a very current challenge from an environmental and economic point of view. There are many initiatives, which improve local product based regional capacities in the EU and in Hungary as well (Balázs 2012). The aim of this study is to strengthen local food economies and to identify local obstacles via an example case of an attractive Hungarian town Eger, with its touristic functions, including wine and local food. Even though the wine region and its surrounding area has considerable traditions for producing of local food, it is still in the initial phase in the regional economy nowadays. There are many producers of cheese, meat, fish, fruits or honey, but they have not got enough capacity to manage their markets. Some of them have already built up cooperation with each other for marketing purposes. It would be necessary to establish similar cooperation networks and trade union structures to support their efforts and their market share. However, local food producers are generally active in the processing and trading but with limited raw material producing capacities. (WINTER 2003)

\section{Material and methods}

This study will reveal the initial situation of the local food economy surrounding Eger. Eger is a small town with 53.000 inhabitants near to the capital city of Hungary (Hungarian Central Statistical Office 2019). Its economy based on tourism and wine with several plants mostly in automotive industry. We used statistical sampling with our own questionnaire (104 examples) as well, and research interviews to collect all relevant data together. We made personal interviews with producers of different local products, like cheese, meat, fish, honey, syrup and jam, herb, bread, wine, etc. According to the opinions of these local producers related mostly to the regional food based economic development, we applied methods from project management to analyze the current situation and to structure the needs and demands of interventions. SWOT analysis, problem-tree, objective-tree and $\log$-frame were the most adequate tools to reveal and to find the potential solutions to reinforce the local food-based economy (Verzuh 2005). Moreover, we established a platform to contribute local food initiatives and cooperation fostering food based rural development and to get to know the most relevant challenges of the local producers and their ventures. 


\section{Results}

The Eger wine region has a significant local food capacity and there are different kinds of local food producers with lots of product offers. They are in different stages in terms of the evolution of small businesses and they have limited information about the local market and consumption (CHURCHILL-Lewis; 1983). To reach local or regional markets it is important to have a marketing and business strategy as well, but the local producers have scanty capacities to achieve marketing concepts and they have mostly initial business plans. Most of them have other jobs to provide for their living expenses. Moreover, they have limited opportunities to participate in the local gastronomy events because of the high prices and they do not have an adequate representation of interest. They are handled as a marginal part of the whole food industry, which is a very disadvantageous status for them.

According to the opinions of local customers there is a significant demand for local food products especially for wine, cheese, bakery products, fruit, milk, honey, eggs etc. Meat has an average demand, but fish or syrup is less popular, than the others with the local consumers.

The well-known local food producers in most cases are wineries or cheese producers and since the polling was conducted in Eger the most active producers, like Sáfrány Pisztráng (Safrany’s trout), Rigó Teák (Rigo’s teas), or jam and honey small businesses. Consumers behavior supports the specialized expectations of local food producers, that are commonly known for their quality, special taste of food, reliability, sustainability, circular economy (so that the money stays in the community), etc.

Despite the popularity of local producers, they have limited opportunities to participate in the regional market. First, they have insufficient information and access to the local markets due to marketplace fees or other costs. Some of them are suppliers of local restaurants or they try to sell their products nearby in the shopping malls. Eger does not have dedicated stores to offer local food products for citizens and tourists, and according to the opinion of the producers, they would support a regional shop network, which already exists in the polish tourist city of Zakopane. The local food shops in Zakopane offer many types of local products in unique styles and tastes (see Fig 1.). 


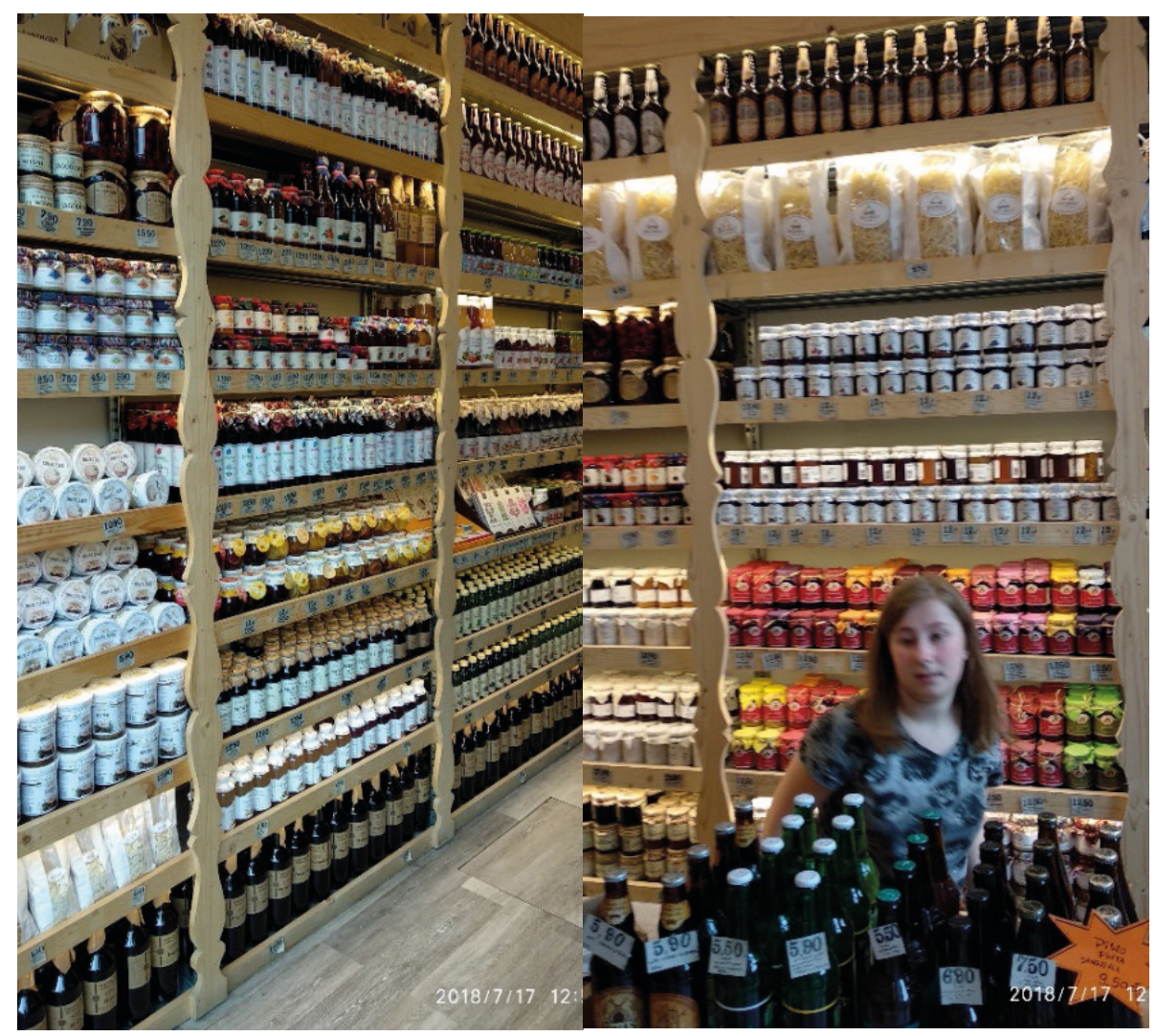

Figure 1 Local food shop in Zakopane (Poland) - own picture

To explore the local food-based economy in the Eger wine region, we have created a SWOT analysis, which synthesizes the most adequate cases of the local food market in the wine region. The results of the SWOT analysis call attention to the current situation of the local food economy, which has relatively good fundaments to improve and accomplish a higher level. There are many positive factors in existing food producers in the region, which include their own product ranges, labels, small scale professional and business cooperation, raw materials mostly from the region and a variety of their product supply (wine, cheese, meat, fish, herbs, honey, jams and syrups, etc.). 


\begin{tabular}{|c|c|}
\hline Strengths & Weaknesses \\
\hline $\begin{array}{l}\text { - Several producers in the region } \\
\text { - Unique and labeled local products } \\
\text { - } \text { Relatively broad product lines } \\
\text { - Increasing of demand for local food } \\
\text { - Good examples of local businesses } \\
\text { (Bükk Mountain Cheese, Sáfrány } \\
\text { Trout, Soma Meat, Rigós tea, etc.) } \\
\text { - Supporting the local circular } \\
\text { economic development } \\
\text { - Available subsidies for infrastructure } \\
\text { - Sevelopment } \\
\text { fupport to the local producers } \\
\text { Eszterházy University } \\
\text { - Increasing demand for local food in } \\
\text { restaurants } \\
\text { Advantageous geographical } \\
\text { fundaments of raw materials }\end{array}$ & $\begin{array}{l}\text { - Not well-known local producers } \\
\text { - Different lifecycles of local food } \\
\text { businesses } \\
\text { - Limited capacities in production } \\
\text { - Not enough opportunities for } \\
\text { - } \text { Thomotion and sale } \\
\text { - } \text {-xperiences in marketing } \\
\text { - Weak cooperation with each other } \\
\text { - Weak circumstances in protection } \\
\text { - of interests } \\
\text { - } \text { - } \text { - Shouk partnership with the local } \\
\text { - Young people do not find being a } \\
\text { local food producer an attractive job } \\
\text { - Relatively high prices } \\
\text { - Mostly bad experiences in subsidy } \\
\text { application }\end{array}$ \\
\hline Opportunities & Threats \\
\hline $\begin{array}{l}\text { - Eger as center of international } \\
\text { tourism } \\
\text { - Following good examples in local } \\
\text { food branding } \\
\text { - European subsidies for stimulating } \\
\text { local markets } \\
\text { - Fostering participation of the } \\
\text { Hungarian Chamber of Agriculture } \\
\text { The boom in the global economy } \\
\text { could improve the demand of local } \\
\text { products }\end{array}$ & $\begin{array}{l}\text { - The existing dominance of } \\
\text { wholesale trading } \\
\text { - Changing policies in subventions } \\
\text { - Uncertainty in rural development } \\
\text { policies } \\
\text { - Changing consumer attitudes } \\
\text { - Tightening of local food supply in } \\
\text { the region }\end{array}$ \\
\hline
\end{tabular}

Some of them have good cooperation with scientific institutions as well, and they have many common projects with such entities (wine clusters, food analytics, taste of Eger initiative, etc.)

Our survey for the needs of local consumers shows, there is an increasing demand in the local market for local food products. We had interviewed 104 respondents 
about their shopping habits and 10 food producers or winemakers. $96 \%$ of them have bought local products primarily food products and they are convinced that these types of products have a unique quality and a significant value in achieving a healthy life. The consumers know quite well the biggest producers, like wineries and cheese, meat or herb producers. Restaurants are good partners for local producers, but they need a permanent supply, which is not available in all categories of local food offers. (Feldmann-Hamm 2015)

The weaknesses are mostly concerning the gap in the local food economy: there are just a few producers and they are in different lifecycles of business development, which limits their capacities in the local food supply. They are mostly unknown for the local customers, because of limited promotion opportunities. There is a huge lack of marketing knowledge, which is needed for business development. In our opinion, it can be helpful to establish a customized advocacy for local food or product makers, instead of the current situation, that limits their representation to an ordinary way of common agricultural actors. The subsidy system is a restricted opportunity for us, because of rigorous regulations and financial conditions. Training can be an effective way to develop starter venues in this area, but a capable training center is needed to fulfill their demand in business development and marketing. The local university could offer such training events together with the Hungarian Chamber of Agriculture. Tamas Jakab, director of the Chamber in Heves County said, that they are ready to support this formation of local food producers, but it is necessary to separate them from the ordinary food producers. He emphasized, that local producers are mostly interested in producing raw materials, instead of making processed food products. However, there are differences between local processed food and local produced food ingredients. Both are available on local marketplaces, if they require only small scale offers, but there is lack of big producers in the processed local food segment.

Rural areas have considerable issues in the shortage of labour in the Northern Hungarian Region; furthermore, it is not an attractive job for young people to be local product makers. Local products cost slightly more than ordinary food products, because of handmade production, and the small scale of production capacities.

Subsidies would play a very important role in the operation of rural enterprises; however local actors and food producers have disadvantageous experiences in applying rural economic development projects.

The external environment of the local food-based economy in the wine region has a rather positive impact on the food producers. Eger and its region have international role in tourism and can provide an advantageous market for local product producers, although these are yet only possibilities. (Jónás-Berki et. al. 2015) The dominance of wholesale trading, changing development policies and consumer attitudes limit the chances of local products, but the stable economic growth and a technical support of local governmental institutions can strengthen efforts for a local food-based economy. 


\section{Conclusion}

This paper reveals the potentials and components of the local food economy in the wine region. According to the results of the local food-based research in the Eger wine region it can be stated, that there are multiple fundaments of the local food-based economy in the research area. The question was, how is it possible to make more effort to create a local food-based economy, which is more sophisticated than ever before, with the goal that this sector of the local economy would strengthen regional value chains and environmental solutions. The Eger Wine region has relatively good conditions to develop its own local-food based economy with more GO and NGO advocacy, targeted marketing strategy and a considerable development of market infrastructures.

\section{References}

[1.] Balázs B. (2012): Local food system development in Hungary. International Journal of Sociology of Agriculture and Food, 19(3): 403-421.

[2.] Lewis, Virginia L. and Churchill, Neil C., The Five Stages of Small Business Growth (1983). Harvard Business Review, Vol. 61, Issue 3, p. 30 50 1983. Available at SSRN: https://ssrn.com/abstract $=1504517$

[3.] Winter, M. (2003) Embeddedness, the new food economy and defensive localism, Journal of Rural Studies, Volume 19, Issue 1, 2003, Pages 23-32, ISSN 0743-0167, https://doi.org/10.1016/S0743-0167(02)00053-0

[4.] Verzuh, E. (2006): Projektmenedzsment. HVG Zrt, Budapest. pp. 424.

[5.] Jónás-Berki, M., Csapó, J., Pálfi, A., and Aubert, A. (2015) A Market and Spatial Perspective of Health Tourism Destinations: The Hungarian Experience. Int. J. Tourism Res., 17: 602-612. https://doi.org/10.1002/jtr.2027

[6.] Feldmann, C., Hamm, U. (2015) Consumers' perceptions and preferences for local food: A review, Food Quality and Preference, Volume 40, Part A, 2015, Pages 152-164, ISSN 0950-3293, https://doi.org/10.1016/j.foodqual.2014.09.014

[7.] https://www.ksh.hu/docs/hun/hnk/hnk_2019.pdf 